Rev. Biol. Trop., 47(1-2): 237-238, 1999

www.ucr.ac.cr www.ots.ac.cr www.ots.duke.edu

\title{
Colonization of Socorro Island (Mexico), by the tropical house gecko Hemidactylus frenatus (Squamata: Gekkonidae)
}

\author{
Patricia Galina-Tessaro, Alfredo Ortega-Rubio, Sergio Alvarez-Cárdenas and Gustavo Arnaud \\ Centro de Investigaciones Biológicas del Noroeste. Apartado Postal No. 128, La Paz, 23070 B.C.S México. Fax \\ (112) 55343; e-mail: pgalina@ cibnor.mx.
}

Received 1-V-1998. Corrected 16-XI-1998. Accepted 4-XII-1998.

Hemidactylus frenatus Schlegel is a nocturnal lizard widely distributed in Southern Asia, the Pacific Islands, tropical Africa, Australia and Polynesia (Smith and Taylor 1950, Bustard 1970). Introduced in México, $H$. frenatus apparently is becoming more widespread by human agency (Hardy and McDiarmid 1969, Stebbins 1985). The Revillagigedo Archipelago, Mexico, especially Socorro Island, is very important to both national and global biodiversity (Ortega et al. 1991). Socorro Island exhibits high incidence of endemic taxa and alarming problems caused by introduced species (Ortega et al. 1992). Despite the biological importance of this island, few scientific works dealing with its herpetofauna have been published (Hanna 1926, Brattstrom 1955, 1982, Richards and Brattstrom 1959). None of these works report the presence of $H$. frenatus on Socorro Island. In this article we document the first record of this successful colonizing species on Socorro Island; additionally we discuss data of the reproductive condition and diet of the specimens collected.

During February 1990 we traversed Socorro Island during seven nights looking for nocturnal lizards. During three additional nights on the same month we collected 29 Hemidactylus frenatus specimens between 19:00 and 02:00 hrs at the buildings of the Navy Garrison. Stomach contents were removed and examined with a stereomicroscope. The 29 analyzed stomachs yielded 86 individual food items, which were identified to order level. Lengths and widths of prey items were obtained with an optical micrometer and their volumes were calculated assuming that prey items were cylindrically shaped. For the males, each testis was measured with an optical micrometer. For the females, the number, length and width of each oviductal egg were recorded, as well as the number and size of each ovum with vitellus and without vitellus in their ovaries.

The geographic distribution of Hemidactylus frenatus on Socorro Island was restricted to the human buildings of Navy Garrison at the time of our survey. Average SV length and body mass of the 14 collected males was $49.00 \mathrm{~mm}(\mathrm{SD}=8.95)$ and $3.31 \mathrm{~g}(\mathrm{SD}=$ $1.04)$, and $45.10 \mathrm{~mm}(\mathrm{SD}=6.34)$ and $2.56 \mathrm{~g}$ $(\mathrm{SD}=0.87)$ for the 15 collected females. Lepidoptera were the most abundant prey items consumed, both in frequency (44\%) and volume $(43 \%)$ respectively, followed by 
Orthoptera and Aranea (15\% and 9\% respectively in volume). Our results on the diet of $H$. frenatus on Socorro Island are consistent with those reported in the literature for other places (Bobrov 1992), except that we found that cannibalism was occurring (21\% of the total volume of prey items consisted of gecko remains).

Twenty percent of the collected females had oviductal eggs. The smallest female found with oviductal eggs had $47 \mathrm{~mm}$ SVL. Males also appeared to exhibit signs of reproductive activity: $28.6 \%$ showed enlarged deferent ducts and the total average size of the testes was $4.04 \mathrm{~mm}$ in length and $2.60 \mathrm{~mm}$ in width. According to our results both males and females show evidence of reproductive activity during February.

On Socorro Island there is only one other reptile, the endemic diurnal lizard Urosaurus auriculatus (Cope). For this reason, and because Hemidactylus frenatus has been demonstrated to be a successful colonizer, it is important to develop further studies on the ecology and biology of this gecko, particularly those focused with their relationships with the native vertebrate fauna, specially the endemic diurnal lizard, in order to establish the ecological significance of this exotic colonizing species in a threatened and very fragile insular ecosystem.

This study was funded by the Centro de Investigaciones Biológicas del Noroeste (CIBNOR), the Consejo Nacional de Ciencia y Tecnología (CONACyT) of Mexico, and by the USA World Wildlife Fund (WWF). Thanks to three anonymous reviewers who improved an early version of the manuscript and to Lolita Vázquez who provided expert secretarial assistance.

\section{REFERENCES}

Brattstrom, B.H. 1955. Notes on the herpetology of the Revillagigedo islands, México. Amer. Midl. Nat. 54: 212-229.

Brattstrom, B.H. 1982. The comparison of the social behavior of Urosaurus auriculatus and $U$. clarionensis on the Revillagigedo Islands, Mexico. Herpetology 13: 11.

Bobrov, V.V. 1992. Ecology of the common house gecko, Hemidactylus frenatus (Reptilia, Sauria, Gekkonidae) in Vietnam. Zool. Zh. 71 (6): 86-90.

Bustard, H. R. 1970. Activity cycle of the tropical house gecko, Hemidactylus frenatus. Copeia (1970) 1: 173-176.

Hanna, G. D. 1926. Expedition to the Revillagigedo Islands, Mexico, in 1925. Proc. Calif. Acad. Sci. 15: $1-113$.

Hardy, L. M. \& R. W. McDiarmid 1969. The amphibians and reptiles of Sinaloa, Mexico. Univ. Kansas Publ. 18: $39-252 \mathrm{p}$.

Ortega-Rubio A., S. Alvarez, P. Galina \& G. Arnaud. 1991. Microhabitat spatial utilization by Socorro's Island lizard Urosaurus auriculatus (Cope). J. Arizona-Nevada Acad. Sc. 24-25: 55-57.

Ortega, A., A. Castellanos, G. Arnaud, Y. Maya, R. Rodríguez, J.L. León, J. Cancino, C. Jimenez, J. Llinas, S. Alvarez, P. Galina, A. Breceda, E. Troyo, F. Salinas, S. Díaz, R. Servín, H. Romero, A. Rodríguez \& R. Coria. 1992. Estudio de los recursos naturales de la Isla Socorro, Revillagigedo. Ciencia 43: 175-184.

Richards, A.F. \& B.H. Brattstrom. 1959. Bibliography, cartography, discovery and exploration of the Isla Revillagigedo. Proc. Calif. Acad. Sci., Ser 4, 29: 315-360.

Smith, H. M. \& E.H. Taylor 1950. An annotated checklist and key to the reptiles of Mexico exclusive of snakes. Bull. U. S. Nat. Mus. 199:1-253.

Stebbins, R C. 1985. A field guide to western Reptiles and Amphibians. Houghton Mifflin, Boston, Massachussetts. 336 p. 